\title{
DRYING KINETICS AND CHEMICAL COMPOSITION OF CERATOTHECA SESAMOIDES ENDL LEAVES
}

\author{
T.A. Morakinyo, C.T. Akanbi, O.I. Adetoye \\ Department of Food Science and Technology, \\ Obafemi Awolowo University, Ile-Ife, Osun Styate, Nigeria
}

\begin{abstract}
This study focused on the drying kinetics of Ceratotheca sesamoides (False sesame) leaves, determination of its proximate and mineral compositions. The leaves of Ceratotheca sesamoides at $\mathbf{8 8 . 5 9 \%}$ moisture content (wb) were obtained, sorted, graded and subjected to a thin layer drying operation using hot air oven at varying drying temperatures of 50, 60 and $70{ }^{\circ} \mathrm{C}$. Drying data obtained were fitted into eight mathematical models; Page, Modified Page, Midili, Newton, Two-term, Henderson and Pabis, Logarithmic and Modified Henderson and Pabis. They were compared in values according to their coefficients of determination $\left(\mathbf{R}^{2}\right)$ and Standard Error of Estimate (SEE). Results showed that Page model provided the best fit for the drying of Ceraotheca sesamoides leaves. The study also showed that drying process occurred in the falling rate period while the drying curve investigated was characterized by a progressive decrease in drying time with increase in drying temperature. The results of the proximate composition, of the dried leaves at varying temperatures showed that crude protein was in the range (23.92-24.15\%); total ash (6.12-7.53\%); moisture content $(9.03-9.38 \%)$; crude fibre (8.09-8.22\%); fat (2.98-3.08\%), and carbohydrate (48.10-49.63\%). Mineral elements analysis of calcium, zinc, phosphorus and iron were also in the range 229.70 277.75, 30.85-78.30, 4.38-4.40 and 85.05-185.20 mg/100g, respectively while Vitamin $\mathrm{C}$ was found in the range 59.29-208.15 $\mathrm{mg} / 100 \mathrm{~g}$. The study provided useful information on the optimum drying condition of Ceratotheca sesamoides and also showed that Ceratotheca sesamoides is an exotic vegetable in terms of its nutritional composition.
\end{abstract}

Keywords- Ceratotheca sesamoides, drying kinetics, proximate composition, minerals, Vitamin $\mathrm{C}$.

\section{INTRODUCTION}

Ceratotheca sesamoides Endl otherwise called false sesame is a leafy vegetable in the Pedaliaceae family of plants. It is indigenous in Africa with about five cultivars and grown wildly in most countries especially in sub-Sahara (Abels, 1975). Some of its local name includes $E k u$ in Yoruba
(South-western Nigeria), Karkashi (Northern Nigeria), Tchaba-laba (Guinea Bissau) and Lalu-caminho (Senegal) (Bedigian, 2003, Abiodun, 2017). Ceratotheca sesamoides leaves tolerates heat and drought with high resistance to adverse conditions, where other vegetables cannot survive. This characteristic enhances its wild distribution in various parts of Africa as weed, commonly dispersed by wind and rainfalls (Bedigian, 2003). In Nigeria and Uganda, it is sown in fields and intercropped with okra, eggplant, cowpea, amaranth, sorghum, sweet potato and sesame on well-drained sandy soils (Bedigian, 2004).

The harvested fresh green leaves are consumed as a vegetable mixed with groundnut flour, salt and a little hot water and cooked for a few minutes as soup. Towards the dry season, harvested leaves can be dried, milled and stored inside bottle, to be reconstituted during its off-season as soup (Burkill, 1997). However, a shift from over dependence on major food crops and vegetables to underutilized edible indigenous crops has been reported to enhance food security globally (Prescott-Allen, 1990; Schippers, 1997). Ceratotheca sesamoides leaves are an underutilized vegetable with a lot of industrial potential and benefits due to its rheological property that can be exploited as binding agent. Generally, green leafy vegetable constitutes an indispensable constituent of human diet, as it adds to the taste and flavour of the dish, as well as protein, fibre, minerals, and vitamins in substantial amounts (Fasakin, 2004; Ejoh et al., 2005). In Africa, Ceratotheca sesamoid leaves are mostly consumed as cooked complements to the major staple foods, like yam, plantains, guinea corn, cocoyam maize, millet, rice and cassava. The amounts of the nutrient constituents and functional properties of the most commonly used leafy vegetable species in Nigeria have been reported (Fasakin, 2004; Famurewa and Akinmuyisitan, 2014). However, Ceratotheca sesamoides leaves remain virtually neglected and under-exploited despite its domestic and industrial application.

Vegetables are highly perishable food crops due to high moisture content which vary between $67-96 \%$ (Alonge and Adeboye, 2012). This condition necessitates for immediate drying operation as the oldest method of food preservation that inhibits the microbial, biochemical spoilage and enzymatic reaction (Krokida and Marinos-Kouris, 2003). 


\section{International Journal of Engineering Applied Sciences and Technology, 2020 \\ Vol. 5, Issue 4, ISSN No. 2455-2143, Pages 442-444 \\ Published Online August 2020 in IJEAST (http://www.ijeast.com)}

Drying also enhances storage life, minimizes losses during storage, and saves shipping and transportation costs (Doymaz, 2005). To determine the drying behaviour of vegetables a thin layer drying medium has been famously adopted by several researchers (Akpinar et al., 2003). It was observed over decades in Africa, that Ceratotheca sesamoides leaves processed by local consumers adopted unscientific techniques. Hence investigating appropriate drying conditions of this leaves will definitely provide adequate post-harvest techniques that will enhance its appropriate handling, support maximum nutritional benefits, storage, packaging and industrial application which are yet to be reported. Hence, the objectives of this research were to determine the drying kinetics of Ceratotheca sesamoides leaves using convective oven at varying temperatures and subjected data obtained to widely used drying models and finally determine the proximate and mineral composition.

\section{MATERIALS AND METHODS}

The harvested fresh mature leaves of Ceratotheca sesamoides were obtained from a local farmer in Ile-Ife, Osun state. The leaves were identified at Department of Botany, Faculty of Science, Obafemi Awolowo University, Ile-Ife. All chemical reagents used were of analytical standard.

\subsection{Sample Preparation}

The leaves were stripped-off from the stems, sorted and graded to remove damaged and extraneous materials then rinsed in clean water and drained. About $150 \mathrm{~g}$ of the cleaned leaves was weighed, spread in thin layers on a tray and loaded inside a hot air oven (SM9053, Uniscope, England) operated at air velocity of $0.13 \mathrm{~m} / \mathrm{s}$ with ambient air humidity between 0.008 and $0.010 \mathrm{~kg} / \mathrm{kg}$ dry air. The drying operation was observed for three different temperatures $\left(50,60\right.$ and $\left.70^{\circ} \mathrm{C}\right)$ sequentially until constant weight at each temperature was obtained. Loss in weight at an interval of an hour was recorded at each steady drying temperature for $24 \mathrm{hrs}$ until bone dry weight was obtained. The dried leaves of three different drying temperatures were labelled and kept inside three desiccators with silical gel. The dried leaves were milled separately into fine powder of $100 \mu \mathrm{m}$ particle size using a blender (Kenwood BL705) for proximate composition and mineral content determination. Ceratotheca sesamoides flour was prepared using the procedures reported by (Famurewa and Akinmuyisitan, 2014).

\subsection{Drying Kinetics}

The loss in weight of each sample was obtained at one 10 min interval under steady drying temperature till dry bone weight was reached. The weight of the dry bone sample was obtained by drying continuously for 24 hours. The experimental data of sample mass $(\mathrm{g})$ against time $(\mathrm{t})$ at each steady drying temperature were used for plotting drying curve and the drying rate curves were obtained by method of tangents (Johnson et al., 1998). The moisture contents of the leaves on the wet basis (w.b) and dry basis (d.b) were determined using Equations 1 and 2. The moisture ratio (MR) of the leaves samples was determined using Equation 3. Drying curves were generated from the experimental drying data to plot the graph of moisture ratio versus time (Equation 4).

$$
\text { Drying rate }=\frac{\text { change in moisture content }(g)}{\text { change in time }(t)}
$$

$\%$ Moisture content $(\mathrm{db})=\frac{\mathrm{w}-\mathrm{w}_{\mathrm{s}}}{\mathrm{w}_{\mathrm{s}}} \times 100$

$\%$ Moisture content $(w b)=\frac{W-W_{S}}{W} \times 100$

where; $\mathrm{W}=$ weight of dried solid + moisture $(\mathrm{g})$

$\mathrm{W}_{\mathrm{s}}=$ weight of dried solid/ dry bone weight $(\mathrm{g})$

$\mathrm{MR}=\frac{\mathrm{M}-\mathrm{M}_{\mathrm{e}}}{\mathrm{M}_{\mathrm{i}}-\mathrm{M}_{\mathrm{e}}}=\exp (\mathrm{kt})$

where; $\mathrm{MR}=$ Moisture ratio, $\mathrm{M}=$ Moisture content at any time' $\mathrm{t}$ ' (kg water/ kg dry matter) $(\% \mathrm{db}), \mathrm{M}_{\mathrm{e}}=$ Equilibrium moisture content (EMC) at the conditions of the drying air (kg water/ kg dry matter) $(\% \mathrm{db}), M_{i}=$ Initial moisture content of sample ( $\mathrm{kg}$ water/ $\mathrm{kg}$ dry matter), $(\% \mathrm{db}), \mathrm{t}=$ Drying time $(\mathrm{min})$ and $\mathrm{k}=$ Drying constant $\left(\mathrm{min}^{-1}\right)$.

\subsection{Mathematical modelling of drying curves}

For this study, eight (8) existing mathematical models (Table 1) were used to predict appropriate model that suit drying curves. These models are: Henderson and Pabis, Page, Modified Page, Logarithmic, Two term, Newton, Midili and Modified Henderson and Pabis.

\subsection{Proximate Composition and Mineral content determination}

Proximate compositions (carbohydrate, protein, fibre, fat and ash) were determined using official methods described by AOAC (2002). The analysis for mineral elements (calcium, iron and zinc) of the samples was determined using atomic absorption spectrophotometric method (Fashakin, 2004). The total phosphorus content was measured using Auto-analyser and Ascorbic acid content in each sample was determined using titrimetric method described by Rekha et al. (2012). 
International Journal of Engineering Applied Sciences and Technology, 2020

Vol. 5, Issue 4, ISSN No. 2455-2143, Pages 442-444

Published Online August 2020 in IJEAST (http://www.ijeast.com)

Table 1: Mathematical Models

\begin{tabular}{lc}
\hline Model & Equation \\
\hline Page & $\mathrm{MR}=\exp \left(-k t^{n}\right)$ \\
Modified page & $\mathrm{MR}=\exp [(-k t)]^{n}$ \\
Henderson and Pabis & $\mathrm{MR}=a \exp (-k t)$ \\
Logarithmic & $\mathrm{MR}=a \exp (-k t)+c$ \\
Modified Henderson and Pabis & $a \exp (-k t)+b \exp (-g t)+c \exp (-h t)$ \\
Newton & $\mathrm{MR}=\exp (-k \mathrm{t})$ \\
Two term & $\mathrm{MR}=a \exp \left(-k_{0} t\right)+b \exp \left(-k_{1} t\right)$ \\
Midili & $M R=\exp \left(-k t^{n}\right)+b t$
\end{tabular}

$\mathrm{MR}=$ Moisture Ratio; $\mathrm{t}=$ temperature; $\mathrm{k}, \mathrm{n}, \mathrm{a}, \mathrm{b}, \mathrm{c}, \mathrm{g}, \mathrm{h}, \alpha, \beta$ are empirical constants in the drying models

Source: Aregbesola et al, (2015)

\subsection{Statistical Analysis}

The suitability of the drying models was determined by comparing three evaluation indicators for each model. These indicators were: residual sums of squares (RSS), the sum of the square error (SEE) and co-efficient of determination $\left(\mathrm{R}^{2}\right)$ as an index of variability between the experimental and predicted data as shown in various Equations (Akanbi et al., 2006, Cordeiro et al., 2006, Oyelade, 2008).

$R S S=\sum_{i=1}^{n}\left(M_{\text {calculated }}-M_{\text {predicted }}\right)$

$\mathrm{SEE}=\sqrt{\frac{\sum_{i=1}^{n}\left(M_{\text {calculated }}-M_{\text {predicted }}\right)^{2}}{d . f}}$

$R^{2}=\left(1-\frac{R S S}{T S S}\right)$

where: $\mathbf{M}_{\text {calculated }}=$ equilibrium moisture content $($ EMC) by experiment, \% wet basis;

$\mathrm{M}_{\text {predicted }}=$ predicted EMC due to models, \% wet basis; RSS = residual sum of squares;

TSS $=$ total sum of squares; d.f. $=$ total degree of freedom.

The TSS value was obtained from the ANOVA (Analysis of Variance) as table of the non-linear regression model. Data obtained from proximate analysis of three samples leaves powders and their corresponding mineral contents were subjected to inferential and differential statistical analysis.

\section{RESULTS AND DISCUSSION}

\subsection{Drying Characteristics of Ceratotheca sesamoides Leaves}

The drying temperatures used were: 50,60 and $70{ }^{\circ} \mathrm{C}$ and resident time for their dry bone were: 310,160 and 100 mins, respectively. Non-dimensional Moisture Ratio (MR) was plotted against drying time as shown in Fig. 1. The plots followed the general trend of drying curves as reported by many previous researchers (Ahmed and Shivhare 2001; Davinder and Shashi 2005; Arslan et al., 2011). A steeper curve was obtained at $70{ }^{\circ} \mathrm{C}$ due to its high temperature, thereby exhibiting an increase in drying rate, followed by $60{ }^{\circ} \mathrm{C}$ and $50{ }^{\circ} \mathrm{C}$ (Rayaguru and Routray, 2010).

The drying process was characterized by a progressively decreasing moisture content with time (Fig.1). It was observed that the evaporation rates were higher at the beginning of the drying process (initial phase) with the drying temperature of $70{ }^{\circ} \mathrm{C}$ having the highest drying rate while the lowest drying rate occurred at $50{ }^{\circ} \mathrm{C}$. This same trend was reported by Rayaguru and Routray, 2010; Arslan et al., 2011 that higher drying temperatures increase mass and heat transfer in food material. Hence, it was observed that the higher the drying temperature, the shorter the drying time. It could be inferred from these results that drying time depends mainly on the drying air temperature. These results correlated with the reports of previous researchers on the drying of fruits and vegetables (Akpinar et al., 2003; Midilli and Kucuk, 2003; Gunhan et al., 2005; Nguyen and Price, 2007; Wang et al., 2007; Motevali et al., 2010). There was no any constant rate drying period in the drying process of Ceratotheca sesamoides leaves. Likewise, the entire drying process occurred in the falling rate period only as depicted in Fig. 1. This may be due to the absence of interstitial 


\section{International Journal of Engineering Applied Sciences and Technology, 2020 Vol. 5, Issue 4, ISSN No. 2455-2143, Pages 442-444 \\ Published Online August 2020 in IJEAST (http://www.ijeast.com)}

water in plants products (Ghnimi et al., 2016). Falling rate period is often the characteristics of most agricultural products as reported by Karel and Lund (2003); Ramaswamy and Marcotte (2006) and Velic et al. (2007).

\subsection{Modelling of the thin layer drying kinetics}

The drying data were fitted to eight (8) models as presented in Table 1 (Page, Modified Page, Newton, Henderson and Pabis, Modified Henderson and Pabis, Logarithmic, Two term and Midili models). These models have been used by several authors (Akpinar, 2006; Famurewa and
Akinmuyisitan, 2014) for the drying of food materials. The results of coefficient of determination $\left(\mathrm{R}^{2}\right)$ and the standard error of estimate (SSE) for each of the models are shown in Table 2. At $50{ }^{\circ} \mathrm{C}$ drying temperature, the $\mathrm{R}^{2}$ values of the models ranged from 0.9599 to 0.9997 , and SSE from 0.0048 to 0.0540 . The Page model gave the highest $\mathrm{R}^{2}$ value of 0.9997 and SEE values of 0.0048. Midili model had the lowest $\mathrm{R}^{2}$ value of 0.9599 and highest value of SEE 0.0540 . This implies that the Page model best described the drying process at $50{ }^{\circ} \mathrm{C}$.

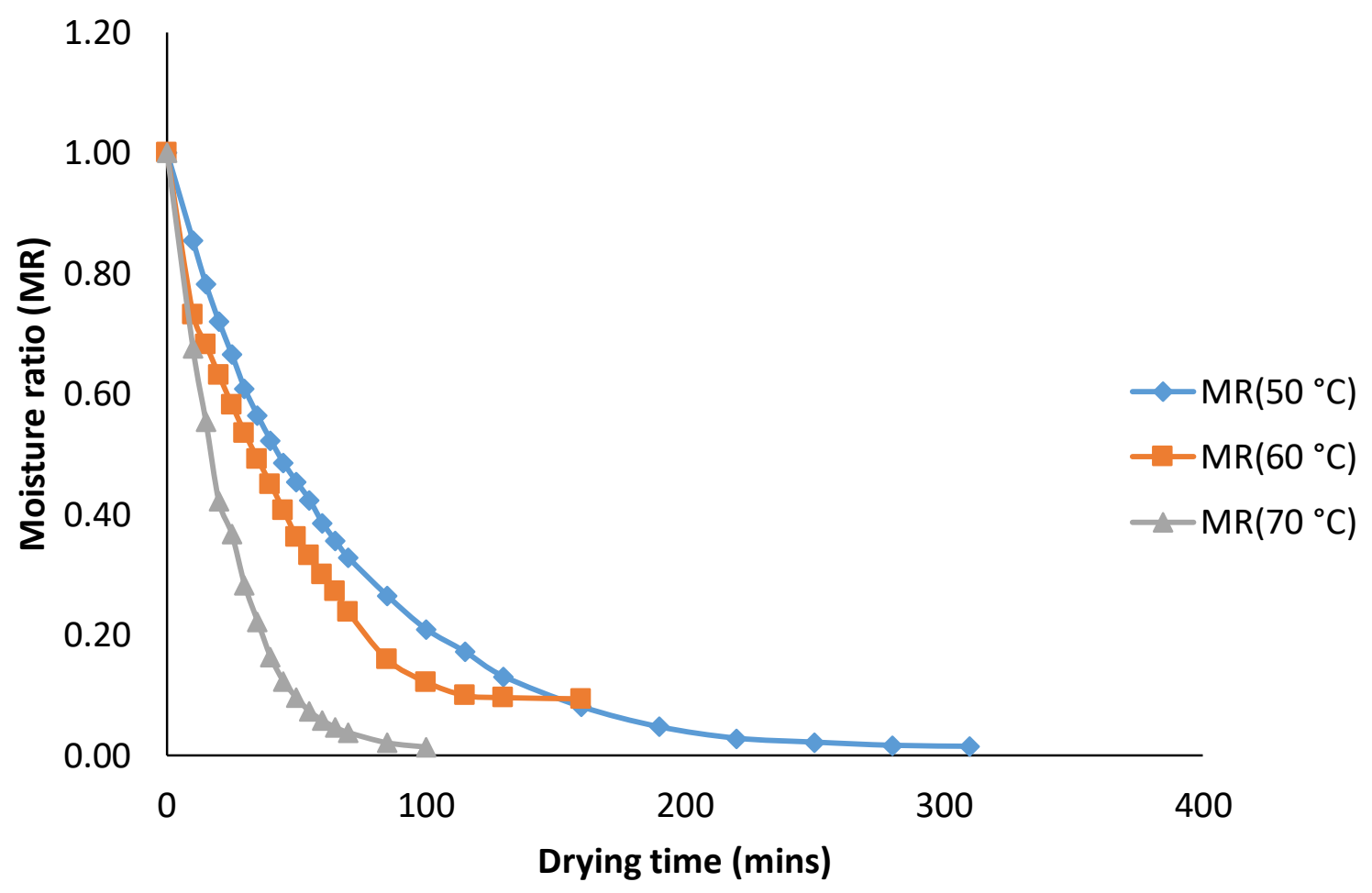

Figure 1: Moisture ratio at different drying temperatures

At a drying temperature of $60{ }^{\circ} \mathrm{C}$, the $\mathrm{R}^{2}$ values of the models ranged from 0.9760 to 0.9940 , and SEE from 0.0200 to 0.0417 . The Midili model had the highest values for $\mathrm{R}^{2}(0.99401)$ with lowest value of SEE (0.0200). This implies that the Midili model best described the drying process at $60{ }^{\circ} \mathrm{C}$.

At a drying temperature of $70{ }^{\circ} \mathrm{C}$, the $\mathrm{R}^{2}$ values of the models ranged from 0.99546 to 0.99918 , and SEE from 0.00739 to 0.01497 . The Page model gave the highest $\mathrm{R}^{2}$ value of 0.99918. Comparing $\mathrm{R}^{2}$ and SEE obtained in each drying temperature, it was established that Page model best describe the dying process at $70{ }^{\circ} \mathrm{C}$. Summarily, Page model best describe the thin layer drying of Ceratotheca sesamoides leaves at 50 and $70^{\circ} \mathrm{C}$ while the Midili model describes the process at $60^{\circ} \mathrm{C}$. It was reported that $\mathrm{R}^{2}$ values higher than $97 \%$ could be assumed satisfactory (Mohapatra process. and Rao 2005). From Table 2 , all the models $\mathrm{R}^{2}$ values are higher than 0.97 , hence they can be judged satisfactory in predicting the drying Similarly, Comparing $\mathrm{R}^{2}$ and SEE for all three temperatures it could be inferred that the Page's model and oven drying at $50{ }^{\circ} \mathrm{C}$ gave better fit than other levels of temperatures for economic reason of energy consumption cost, retention of volatile vitamin $\mathrm{C}$ and denaturing of other food components. It also showed that the value of drying constant " $\mathrm{k}$ and $\mathrm{n}$ " increased as temperature increased. This means that the drying curves become steeper as temperature increase and drying process become faster. These results were in correlation with result previously reported by Soysal (2004). The predicted data fit perfectly around the curve which showed the suitability of the Page model in describing the drying behaviour of Ceratotheca sesamoides leaves as depicted in Figure 2. 
International Journal of Engineering Applied Sciences and Technology, 2020 Vol. 5, Issue 4, ISSN No. 2455-2143, Pages 442-444

Published Online August 2020 in IJEAST (http://www.ijeast.com)

Table 2: Coefficients of thin layer drying models and goodness of fit for Ceratotheca sesamoides leaves

\begin{tabular}{|c|c|c|c|c|c|}
\hline $\mathrm{S} / \mathrm{N}$ & Model & $\operatorname{Temp}\left({ }^{\circ} \mathrm{C}\right)$ & Parameters & $R^{2}$ & SEE \\
\hline \multirow[t]{3}{*}{1.} & Newton & 50 & $\mathrm{~K}=0.0159$ & 0.9997 & 0.0051 \\
\hline & & 60 & $K=0.0205$ & 0.9867 & 0.0341 \\
\hline & & 70 & $K=0.0430$ & 0.9972 & 0.0132 \\
\hline \multirow[t]{3}{*}{2.} & Page & 50 & $\mathrm{~K}=0.0178, \mathrm{n}=0.9724$ & 0.9997 & 0.0048 \\
\hline & & 60 & $\mathrm{~K}=-0.0485 \mathrm{n}=-0.7754$ & 0.9760 & 0.0417 \\
\hline & & 70 & $\mathrm{~K}=-0.0297, \mathrm{n}=1.1100$ & 0.9992 & 0.0074 \\
\hline \multirow[t]{3}{*}{3.} & Modified Page & 50 & $\mathrm{~K}=-0.1200, \mathrm{n}=-0.1326$ & 0.9997 & 0.0051 \\
\hline & & 60 & $\mathrm{~K}=-0.1370, \mathrm{n}=-0.1497$ & 0.9868 & 0.0341 \\
\hline & & 70 & $\mathrm{~K}=-0.2026, \mathrm{n}=-0.2121$ & 0.9972 & 0.0132 \\
\hline \multirow[t]{3}{*}{4.} & Henderson & 50 & $\mathrm{~K}=0.0157, \mathrm{a}=0.9915$ & 0.9997 & 0.0055 \\
\hline & and Pabis & 60 & $\mathrm{~K}=0.0189, \mathrm{a}=0.9388$ & 0.9797 & 0.0402 \\
\hline & & 70 & $\mathrm{~K}=0.0438, \mathrm{a}=1.0218$ & 0.9973 & 0.0132 \\
\hline \multirow[t]{3}{*}{5.} & Logarithmic & 50 & $\mathrm{~K}=0.0160, \mathrm{a}=0.9876 \mathrm{c}=0.0068$ & 0.9997 & 0.0049 \\
\hline & & 60 & $\mathrm{~K}=0.0239, \mathrm{a}=0.8968 \mathrm{c}=0.0795$ & 0.9923 & 0.0227 \\
\hline & & 70 & $\mathrm{~K}=0.0438, \mathrm{a}=1.0218, \mathrm{c}=0.000$ & 0.9973 & 0.0132 \\
\hline \multirow[t]{3}{*}{6.} & Midili & 50 & $\begin{array}{l}K=-7.1040, \mathrm{n}=-0.0838 \\
\mathrm{a}=0.0027, \mathrm{~b}=-0.0008\end{array}$ & 0.9599 & 0.0540 \\
\hline & & 60 & $\begin{array}{l}\mathrm{K}=0.0247, \mathrm{n}=0.9599 \\
\mathrm{a}=0.9759, \mathrm{~b}=0.0003\end{array}$ & 0.9940 & 0.0200 \\
\hline & & 70 & $\begin{array}{l}K=0.0216, n=1.1881 \\
a=0.9412, b=0.0000\end{array}$ & 0.9980 & 0.0110 \\
\hline \multirow[t]{3}{*}{7.} & Two Term & 50 & $\begin{array}{l}\mathrm{K}_{0}=0.0124 \mathrm{~K}_{1}=0.0175 \\
\mathrm{a}=0.2883 \mathrm{~b}=0.7068\end{array}$ & 0.9997 & 0.0050 \\
\hline & & 60 & $\begin{array}{l}\mathrm{K}_{0}=0.0189 \mathrm{~K}_{1}=0.0178 \\
\mathrm{a}=0.9253 \mathrm{~b}=-0.0136\end{array}$ & 0.9797 & 0.0403 \\
\hline & & 70 & $\begin{array}{l}\mathrm{K}_{0}=0.0564 \mathrm{~K}_{1}=0.0835 \\
\mathrm{a}=1.9394 \mathrm{~b}=-0.9875\end{array}$ & 0.9983 & 0.0104 \\
\hline \multirow[t]{3}{*}{8.} & $\begin{array}{l}\text { Modified } \\
\text { Henderson }\end{array}$ & 50 & $\begin{array}{l}K=0.0160, a=0.9876 b=-0.000 \\
c=0.0064, g=0.0162, h=-0.000\end{array}$ & 0.9997 & 0.0049 \\
\hline & and Pabis & 60 & $\begin{array}{l}K=0.0238, a=0.2235, b=0.6734 \\
c=0.0795, g=0.0240, h=0.000\end{array}$ & 0.9923 & 0.0227 \\
\hline & & 70 & $\begin{array}{l}\mathrm{K}=0.0438, \mathrm{a}=1.0218, \mathrm{~b}=0.000 \\
\mathrm{c}=0.000 \mathrm{~g}=0.0990, \mathrm{~h}=0.0003\end{array}$ & 0.9973 & 0.0132 \\
\hline
\end{tabular}

$\mathrm{R}^{2}=$ coefficient of determination, $\mathrm{SEE}=$ Standard Error of Estimate 
International Journal of Engineering Applied Sciences and Technology, 2020

Vol. 5, Issue 4, ISSN No. 2455-2143, Pages 442-444

Published Online August 2020 in IJEAST (http://www.ijeast.com)

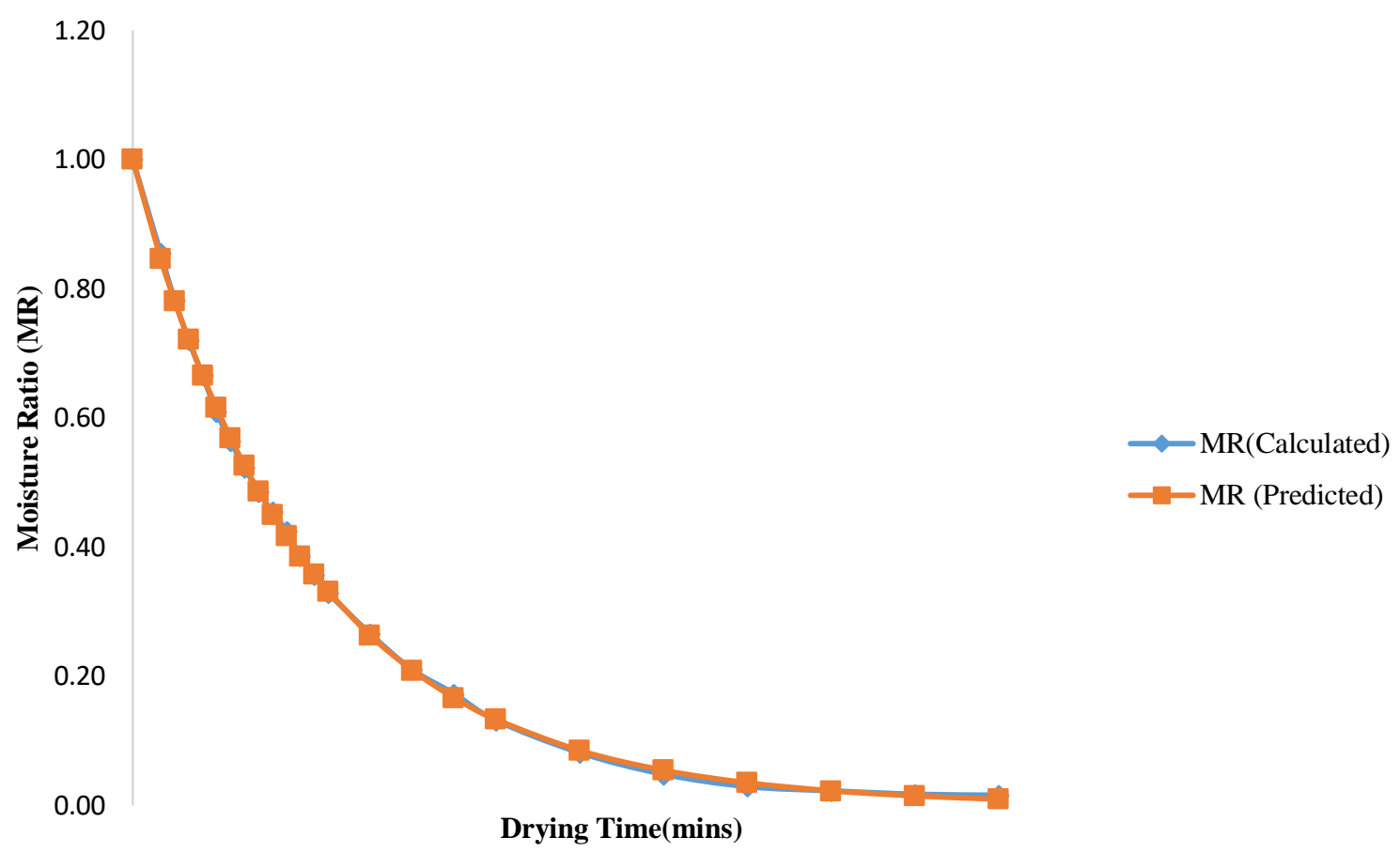

Figure 2. Experimental and Predicted values of moisture ratio of the best fit model (Page Model)

\subsection{Proximate Composition}

\subsubsection{Crude protein content}

Crude protein contents of leaves samples A, B and C were: $23.92,24.15$ and $24.04 \%$, respectively in Table 3 . There was no significant difference $(\mathrm{p}<0.05)$ between the samples. This indicated that increase in drying temperature has no effect on the protein content (Orhuamen et al., 2012). These values were higher when compared to other green leafy vegetables. The values obtained for crude protein of Ceratotheca sesamoides were slightly lower when compared to that of values reported by Fasakin (2004) but higher than results reported by Fasola and Ogunsola (2014) who reported the effect of cultivars and maturity of age of the leaves. These differences may be attributed to the geographical locations, soil type, the cultivars and stage of maturity of the plant (Foidl et al., 2001; Fasakin, 2004; Sreelatha and Padma, 2009).

\subsubsection{Total ash content}

In Table 3, the total ash content of Ceratotheca sesamoides leaves ranged from 6.12 to $7.53 \%$; these values were also lower than value reported by Fasakin, (2004) and Fasola and Ogunsola, (2014). However, sample $\mathrm{C}$ had the lowest ash content which could be due to the increase in drying temperature. The value of ash obtained in this study indicated that Ceratotheca sesamoides leaves may be good sources of minerals.

Table: 3: Proximate Composition (\%) of Ceratotheca sesamoides Leaves

\begin{tabular}{cccc}
\hline & Sample A & Sample B & Sample C \\
\hline Protein & $23.92 \pm 0.05^{\mathrm{a}}$ & $24.15 \pm 0.31^{\mathrm{a}}$ & $24.04 \pm 0.17^{\mathrm{a}}$ \\
Moisture & $9.38 \pm 0.03^{\mathrm{a}}$ & $9.15 \pm 0.08^{\mathrm{ab}}$ & $9.03 \pm 0.24^{\mathrm{b}}$ \\
& & & \\
Fat & $3.01 \pm 0.02^{\mathrm{a}}$ & $2.98 \pm 0.13^{\mathrm{a}}$ & $3.08 \pm 0.01^{\mathrm{a}}$
\end{tabular}


International Journal of Engineering Applied Sciences and Technology, 2020

Vol. 5, Issue 4, ISSN No. 2455-2143, Pages 442-444

Published Online August 2020 in IJEAST (http://www.ijeast.com)

Ash

$6.14 \pm 0.04^{\mathrm{b}}$

$8.22 \pm 0.01^{\mathrm{a}}$

$8.09 \pm 0.02^{\mathrm{a}}$

$48.10 \pm 0.57^{\mathrm{b}}$
$6.12 \pm 0.17^{\mathrm{b}}$

$8.12 \pm 0.11^{\text {a }}$

$49.63 \pm 0.27^{\mathrm{a}}$

Values reported are means \pm standard deviation of triplicate determinations. Mean values of the same row with different superscript are significantly different $(\mathrm{p}<0.05)$.

A: Ceratotheca sesamoides leaves dried at $50^{\circ} \mathrm{C}$, B: Ceratotheca sesamoides leaves dried at $60^{\circ} \mathrm{C}$

C: Ceratotheca sesamoides leaves dried at $70^{\circ} \mathrm{C}$

\subsubsection{Crude fat content}

In Table 3, the crude fat content ranged from 2.98 to $3.08 \%$ with sample $\mathrm{C}$ having the highest value of $3.07 \%$. There was no significant difference between the samples. The values obtained were slightly lower compared to that reported by Fasakin (2004). This may be attributed to differences in cultivars, maturity of age and morphological factors.

\subsubsection{Crude fibre content}

Crude fibre content obtained ranged from 8.09 to $8.22 \%$ as showed in Table3. The three samples were not significantly different $(p<0.05)$ from each other. The values obtained were similar to those reported by Fasakin (2004).

\subsubsection{Carbohydrate content}

Carbohydrate content of the Ceratotheca sesamoides Endl leaves was obtained by difference as shown in Table 3 . The results showed that sample $\mathrm{C}$ has the highest carbohydrate content followed by sample A then sample B. There was no significant difference between samples A and C, however, the high carbohydrate values obtained could be attributed to the increase in the drying temperature (Ejoh et al., 2007). These results were correlated with those reported by Fasakin (2004). However, during the process of dehydration, there were changes in nutritional quality (Singh et al., 2006). The higher the nutrients of the samples obtained the lower its carbohydrates contents.

Table 4: Mineral and Vitamin C content of Ceratotheca sesamoides leaves mg/100g

\begin{tabular}{|c|c|c|c|c|c|}
\hline Sample & Calcium (Ca) & Zinc (Zn) & $\begin{array}{l}\text { Phosphorus } \\
\text { (P) }\end{array}$ & $\begin{array}{l}\text { Iron } \\
\text { (Fe) }\end{array}$ & Vitamin C \\
\hline $\bar{A}$ & $229.70 \pm 0.42^{\mathrm{c}}$ & $3.85 \pm 0.21^{\mathrm{c}}$ & $43.82 \pm 0.01^{\mathrm{ab}}$ & $115.05 \pm 0.35^{\mathrm{c}}$ & $74.45 \pm 4.84^{b}$ \\
\hline B & $277.75 \pm 0.49^{\mathrm{a}}$ & $6.30 \pm 0.57^{\mathrm{a}}$ & $44.01 \pm 0.00^{\mathrm{a}}$ & $133.85 \pm 0.92^{b}$ & $108.15 \pm 2.56^{\mathrm{a}}$ \\
\hline C & $254.85 \pm 0.49^{b}$ & $3.69 \pm 0.14^{\mathrm{b}}$ & $43.86 \pm 0.01^{\mathrm{ab}}$ & $165.20 \pm 0.28^{\mathrm{a}}$ & $59.29 \pm 1.28^{c}$ \\
\hline
\end{tabular}

Values reported are means \pm standard deviation of triplicate determinations. Mean values of the same column with different superscript are significantly different $(\mathrm{p}<0.05)$.

A: Ceratotheca sesamoides leaves dried at $50^{\circ} \mathrm{C}, \mathrm{B}$ : Ceratotheca sesamoides leaves dried at $60^{\circ} \mathrm{C}$

C: Ceratotheca sesamoides leaves dried at $70^{\circ} \mathrm{C}$

\subsection{Mineral Composition of Dried Ceratotheca} sesamoides Leaves

The results of the mineral composition of Ceratotheca sesamoides flour at different drying temperatures $(\mathrm{mg} / 100 \mathrm{~g})$ were depicted in Table 4 . The mineral content is a measure $\mathrm{f}$ amount of specific inorganic compounds present in the food.

\subsubsection{Calcium $(\mathrm{Ca})$}

The calcium content of the flour samples ranged from 229.70 to $277.75 \mathrm{mg} / 100 \mathrm{~g}$. The values were significantly different from one another $(p>0.05)$. These value were found to be in the same trend with the report of Fasakin, (2004) and Grubben and Denton (2004). The higher calcium content was obtained in the leaves samples, this may be due to the calcium pectate association with cell membrane phospholipids necessary in maintenance of cell permeability in the plants. The result also showed that sample B contained higher amount of calcium content.

\subsubsection{Phosphorus (P)}

In Table 4, phosphorus content of samples ranged from 44.08 to $43.86 \mathrm{mg} / 100 \mathrm{~g}$. The results showed that there was no significant difference in phosphorus contents of the three samples. These results were slightly higher than the values reported by Fasakin (2004). This could be due to difference in varieties and age of the plant at harvesting. Phosphorus is important for growth, formation of bones and teeth and for energy metabolism. Phosphorus and calcium function together, contributing to blood formation processes and other supportive structures of the body (Igile et al., 2013). 


\section{International Journal of Engineering Applied Sciences and Technology, 2020 Vol. 5, Issue 4, ISSN No. 2455-2143, Pages 442-444 \\ Published Online August 2020 in IJEAST (http://www.ijeast.com)}

The level of phosphorus obtained showed moderate concentration. Hence, the drying temperatures did not alter the phosphorus composition.

\subsubsection{Iron (Fe)}

The iron content of the leaves flour samples ranged between 115.05 and $165.20 \mathrm{mg} / 100 \mathrm{~g}$. The result showed that there was a significant difference $(\mathrm{p}<0.05)$ between the three samples, with sample $\mathrm{C}$ having the highest value (Table 4). The increased in the drying temperature increases the iron content significantly $(\mathrm{P}<0.05)$. High iron content was also reported by FAO 2010 and Mitchikpe et al. (2008). Iron content was found to be higher in Ceratotheca sesamoides leaves and this could be attributed to the fact that, iron is basically a structural component of the plant pigments, enzymes and cytochromes. Iron is also an essential trace element for normal functioning of the central nervous system and in the oxidation of carbohydrates, proteins and fats (Beard 1993; Umar et al., 2007).

\subsubsection{Zinc $(\mathrm{Zn})$}

The values of zinc content ranged between 3.85-6.30 $\mathrm{mg} / 100 \mathrm{~g}$. Leaves dried at $60^{\circ} \mathrm{C}$ (Sample B) had the highest value (Table 4). Similar results were obtained by Mitchipe et al. (2008). Zinc is essential for the synthesis of DNA, RNA, insulin and function or structure of several enzymes (Brisibe et al., 2009) and an essential micronutrient for human growth and immune functions (Bhowmik, and Chiranjib, 2010). The levels of zinc obtained in this research were similar to those reported by Asaolu et al. (2012). Generally, of all elements examined ( $\mathrm{Zn}, \mathrm{Fe}, \mathrm{P}$ and $\mathrm{Ca}$, calcium has the highest values followed by Iron, phosphorus and Zinc, respectively. These results also showed that Ceratotheca sesamoides is a rich source of essential minerals preferably at lower drying temperature but conversely at high drying temperature. Hence moderate drying temperature of $60^{\circ} \mathrm{C}$ will be most preferred as shown in sample B. This could be recommended for optimum drying of Ceratotheca sesamoides leaves without loss in its mineral contents except for calcium content.

\subsection{Ascorbic Acid Content of Ceratotheca sesamoides}

Ascorbic acid values ranged from 59.29 to $108.15 \mathrm{mg} / 100 \mathrm{~g}$ (Table 4.6) for Ceratotheca sesamoides leaves. Highest vitamin $\mathrm{C}$ content was found in sample $\mathrm{B}$ dried at $60{ }^{\circ} \mathrm{C}$ while the lowest was found in sample $\mathrm{C}$ dried at $70{ }^{\circ} \mathrm{C}$ followed by sample A dried at $50{ }^{\circ} \mathrm{C}$. These values were significantly $(p>0.05)$ different from one another. These results indicate that vitamin $\mathrm{C}$ content was depleted as drying temperature increases. Low value of sample A maybe due to the elongated drying period as compared to other samples. The result obtained was in the same trend reported by other authors (Igwemmar et al., 2013). It also correlated with the report of Famurewa and Akinmuyisitan (2014) on drying of Ewedu (Corchorus capsularis) leaves and drying of worowo (Senecio biafrae) by Famurewa (2011). Vitamin C is known to be lost when exposed to air, light and heat (Ejoh et al., 2007; Mbah et al., 2012; Famurewa and Akinmuyisitan, 2014). The higher mineral and vitamin $\mathrm{C}$ content of Ceratotheca sesamoides shown that this leaves can be compared to the more exotic vegetables like amaranths and spinach. Therefore, for optimum value of vitamin $\mathrm{C}$ in Ceratotheca sesamoides, drying temperature should not exceed $60{ }^{\circ} \mathrm{C}$.

\section{CONCLUSION}

The study concluded that drying process occurred in the falling rate period. Drying curve investigated was characterized by a decreasing drying time with increase in drying temperature. However, out of the eight (8) models investigated, the Page model provided the best fitting for Ceraotheca sesamoides leaves. High proximate composition, mineral and vitamin $\mathrm{C}$ were observed. However, variations in their individual values were dependent on the drying temperature. It can however be concluded that Ceratotheca sesamoides is a nutrient dense vegetable and optimal processing condition for Ceratotheca sesamoides vegetable should not exceed $60{ }^{0} \mathrm{C}$ for maximum keep quality and utilization.

\section{REFERENCES}

1. Abels, J., (1975). The genera Ceratotheca Endl. and Dicerocaryum Boj. Monographs of the African Pedaliaceae 3, 4. Memórias da Sociedade Broteriana 25, Coimbra, Portugal. pp 358.

2. Abiodun, O.A. (2017). Chemical and antioxidant properties of Ceratotheca sesamoides Endl. leaves. Carpathian Journal of Food Science and Technology 9(3): 107-113.

3. Ahmed, J. and Shivhare, U. S. (2001). Effect of pretreatment on drying characteristics and colour of dehydrated green chillies. Journal of Food ScienceTechnology 38: 504-506.

4. Akanbi, C.T., Adeyemi, R.S. and Ojo, A. (2006). Drying characteristics and sorption isotherm of tomato slices. Journal of Food Engineering, 73:157-163.

5. Akpinar, E. K. (2006). Mathematical modelling of thin layer drying process under open sun of some aromatic plants. Journal of Food Engineering 77: 864-870.

6. Akpinar, E.K., Midilli, A. and Bicer, Y. (2003). Single layer drying behaviour of potato slices in a convective cyclone dryer and mathematical modeling. Energy Conversion Managment. 44: 1689-1705.

7. Alonge, A. F. and Adebayo, O. A, (2012). Drying rates of some fruits and vegetables with passive solar dryers. International Journal of Agricultural and Biological Engineering. 5 (4): 83-90. 


\section{International Journal of Engineering Applied Sciences and Technology, 2020 Vol. 5, Issue 4, ISSN No. 2455-2143, Pages 442-444 \\ Published Online August 2020 in IJEAST (http://www.ijeast.com)}

8. Aregbesola, O. A., Ogunsina, B. S., Sofolahan, A. E. and Chime, N. N. (2015). Mathematical modelling of thin layer drying characteristics of dika (Irvingia gabonensis) nuts and kernels. Nigerian Food Journal; 33: 83-89.

9. Arslan, D. and Ozcan, M.M., (2011). Dehydration of red bell-pepper (Capsicum annuum L.): change in drying behaviour, colour and antioxidant content. Food Bioproducts Processing 89: 504-513.

10. Asaolu, S. S., Adefemi O. S., Oyakilome I. G., Ajibulu K. E. and Asaolu M. F. (2012). Proximate and mineral composition of Nigerian leafy vegetables. Journal of Food Research. Vol. 1(3): 214 - 218.

11. Association of Analytical Chemists International AOAC. (2002). Offical methods of analysis of the Association of Official Analytical Chemists (16th ed.). Gaithersburg, USA: AOAC.

12. Beard, J. L., Connor, J. R. and Jones, B. C. (1993). Iron in the brain. Nutrition Reviews, 51(6):157-170.

13. Bedigian, D., (2003). Sesame in Africa: origin and dispersals. In: Neumann, K., Butler, A. and Kahlheber, S. (Editors). Food, fuel and fields: Progress in African archaeobotany. Africa Praehistorica. Heinrich-Barth-Institute, Köln, Germany. pp. 17-36.

14. Bedigian, D., (2004). Slimy leaves and oily seeds: distribution and use of wild relatives of sesame in Africa. Economic Botany 58 (Suppl. S): S3-S33.

15. Bhowmik, D., and Chiranjib, K. P. (2010). A potential medicinal importance of zinc in human health and chronic. International Journal of Pharmaceutical and Biomedical Sciences 1(1): 05-11.

16. Brisibe, E. A., Umoren, U. E., Brisibe, F., Magalhaes, P. M., Ferreira, J. F. S., Luthria, D., Wu, X. and Prior, R. L. (2009) Nutritional characterization and antioxidant capacity of different tissues of Artemisia annua L. Food Chemistry, 115: 1240-1246.

17. Burkill, H.M., (1997). The useful plants of West Tropical Africa. 2nd Edition. Volume 4, Families M-R. Royal Botanic Gardens, Kew, Richmond, United Kingdom. pp 969.

18. Cordeiro, D.S., Raghavan, G.S.V. and Oliveira, W.P (2006) "Equilibrium moisture content models for Maytenus ilicifolia leaves" Biosystems Engineering, 94(2): 221-228.

19. Davinder, D., and Shashi P. (2005). Optimization of drying conditions of garlic slices. Journal of Food Science Technology 42: 348-352.
20. Doymaz, L. (2005). Dry behaviour of green beans. Journal of Food Engineering. 69: 161-165.

21. Ejoh, A. R., Tanya, A.N., Djuikwo, N.V. and Mbofung, C.M. (2005). Effect of processing and preservation methods on vitamin $\mathrm{C}$ and total carotenoid levels of some Vernonia (Bitter leaf) species. African Journal of food Nutrition and Development. 5(2): 105 - 117.

22. Ejoh, R.A., Nkonga, D.V., Innocent, G. and Moses, M.C. (2007). Nutritional components of some nonconventional leafy vegetables consumed in Cameroon. Pakistan Journal of Nutrition. 6(6): 712 $-717$.

23. Famurewa, J. A. V (2011). An Assessment of PhysicoChemical Properties of Worowo (senecio biafrae); Emphasis on Common Drying Methods. Journal of Food Processing and Preservation 35: 327-320

24. Famurewa, J. A. V. and Akinmuyisitan F. A. (2014). Prediction of drying model and determination of effects of drying temperature on Mucilage and Vitamin-C contents of Fluted Jute (Corchorus capsularis) Leaves. African Journal of Food Science Research. 2(11): 149-154.

25. Food Administration Organisation (2010). Composition of selected foods from West Africa.

26. Fasakin, K. (2004). Proximate composition of bungu (Cerototheca Sesamoides Endl.) leaves and seeds. BIOKEMISTRI 16(2): 88 - 92.

27. Fasola, T. R and Ogunsola, O. K. (2014). The proximate and phytochemical composition of Sesamum indicum Linn and Ceratotheca sesamoides Endl at different stages of growth. Journal of Biology, Agriculture and Healthcare. 4(6): 84-88

28. Foidl, N., Makkar, H.P.S. and Becker, K. (2001) Potential of Moringa oleifera in agriculture and industry. Potential of Moringa products development, pp, 20. Food Engineering 20: 55-74.

29. Grubben, G. J. H., and Denton, O. A., (2004). Plant Resources of Tropical Africa 2. Vegetables. 63-89. PROTA Foundation, Wageningen, Netherlands. Backhuys Publishers, Leiden, Netherlands / CTA, Wageningen, Netherlands.

30. Ghnimi, T., Hassini L., Bagane, M. (2016). Experimental study of water desorption isotherms and thin-layer convective drying kinetics of bay laurel leaves. Heat Mass Transfer 52: 2649-2659

31. Gunhan, T., Vedat, D., Ebru, H., Arif, H., (2005). Mathematical Modelling of Drying of Bay Leaves. Energy Conversion and Management 46: $1667-$ 1679.

32. Igile, G.O., Iwara, I.A., Mgbeje, B.I. A., Uboh, F.E. and Ebong, P.E. (2013): Phytochemical, proximate and 


\section{International Journal of Engineering Applied Sciences and Technology, 2020 Vol. 5, Issue 4, ISSN No. 2455-2143, Pages 442-444 \\ Published Online August 2020 in IJEAST (http://www.ijeast.com)}

Nutrient composition of Vernonia calvona Hook (asteracea): A green leafy vevgetable in Nigeria. Journal of Food Research. 2(6): 1 - 11.

33. Igwemmar, N. C. Kolawole, S. A. and Imran, I. A. (2013). Effect of Heating on Vitamin C Content of Some Selected Vegetables International Journal of Scientific and Technology Research 2(11): 209-212.

34. Johnson, P. N. T., Brennan, J. G. and Addo-Yobo, F. Y. (1998). Air drying characteristics of plantain (Musa AAB). Journal of Food Engineering; 37: 233-242.

35. Karel, M. and Lund, D. B. (2003). Physical Principles of Food Preservation. 2nd ed. Marcel Deker, Inc. New York.

36. Krokida, M. K., Marinos-Kouris, D. (2003). Rehydration kinetics of dehydrated products, Journal of Food Engineering, 57(1): 1-7.

37. Mbah, B. O., Eme, P. E. and Paul, A. E. (2012). Effect of drying techniques on the proximate and other nutrient composition of Moringa oleifera leaves from two areas in eastern Nigeria, Pakistan Journal of Nutrition., 11(11): 1044-1048.

38. Midilli A. and H. Kucuk. 2003. Mathematical modeling of thin layer drying of pistachio by using solar energy. Energy Conversion Management. 44: 1111-1122.

39. Mitchikpe, E. C. S., Dossa, R. A. M., Ategbo, E. D., van Raaij, J. M. A., Hulshof, P. J. M., and Kok, F. J. (2008). The supply of bioavailable iron and zinc may be affected by phytate in Beninese children. Journal of Food Composition and Analysis. 21(1):17-25.

40. Mohapatra, D. and Rao, P. S. (2005). A thin layer drying model of parboiled wheat. Journal of Food Engineering, 66(4): 513-518.

41. Motevali A., Minaeiy, S., Khoshtaghazaz, M. H., Kazemi, M. and Nikbakhtyy, (2010). Drying of pomegranate arils: Comparison of predictions from mathematical models and neural networks. International Journal of Food Engineering 6(3): 117.

42. Nguyen H. M. and E. W. Price. (2007). Air drying of banana: Influence of experimental parameters, slab thickness, banana maturity and harvesting season. Journal of Food Engineering. 79(1): 200-207.

43. Orhuamen, E.O., Olorunmaiye, K. S.and Adeyemi, C. O. (2012). Proximate Analysis of Fresh and Dry Leaves of Telfairia occidentalis (Hook.f.) and Talinum triangulare (Jacq.) WilldCroatian Journal of Food Technology, Biotechnology and Nutrition 7 (3-4): 188-191.
44. Oyelade, O.J. (2008), "Equilibrium Moisture Content Models for Lafun" International Journal of Food Engneering 4(2): 229-235.

45. Prescott-Allen and Prescott Allen. (1990). How many plants feed the world? Conservation Biology 4(4): 365-374.

46. Ramaswamy $\mathrm{H}$ and $\mathrm{M}$ Marcotte, (2006). Food processing principles and applications. London: Taylor and Francis Group.

47. Rayaguru, K., Routray, W. (2010): Effect of drying conditions on drying kinetics and quality of aromatic Pandanus amaryllifolius leaves, Journal of Food Science Technology 47(6): 668-673.

48. Rekha C., Poornima G., Manasa M., Abhipsa V., Pavithra Devi J., Vijay Kumar A.T., and Prashith Kekuda, R. 2012. Ascorbic acid, total phenol content and antioxidant activity of fresh juices of four ripe and unripe citrus fruits. Chem. Sci. Trans. 1:303310.

49. Schippers, R. (1997). Domestication of Indigenous Vegetables for Sub-Saharan Africa: A Strategy Paper on African Indigenous Vegetables, Workshop Proceedings, January 13- 18, 1997, Limbe, Cameroon, pp. 125-135.

50. Singh, U., Sagar, V.R., Behera, T.K. and Kumar, P.S. (2006). Effect of drying conditions on the quality of dehydrated selected vegetables. Journal of Food Science and Technology 43: 579-582.

51. Soysal, Y., (2004). Microwave Drying Characteristics of Parsley. Biosystem Engineering 89: 167-173.

52. Sreelatha, S. and Padma, P. R. (2009). Antioxidant activity and total phenolic content of Moringa oleifera leaves in two stages of maturity. Plant Foods for Human Nutrition, 64(4): 303-311.

53. Umar, K.J., Hassan, L.G., Dangoggo, S.M., Inuwa, M. and Mustapha, M.N. (2007): Nutritional content of Melochia corchorifolia (Linn.) leaves. International Journal of Biological Chemistry, 1(4): 250 - 255.

54. Velić D., Bilić, M., Tomas, S., Planinić, M., BucićKojić, A. and Aladić, K. (2007). Study of the drying kinetics of "Granny Smith" apple in tray drier, Agriculturae Conspectus Scientificus, 72(4): 329334.

55. Wang, Z., Sun, J., Chen, F., Liao, X., Hu, X. (2007). Mathematical modelling on thin layer microwave drying of apple pomace with and without hot air predrying. Journal of Food Engineering. 80: 536-54. 